\title{
VELKOMST TIL JUBILÆUMSKONFERENCEN
}

\section{AF FORMANDEN FOR DANSK KriminALISTForenING William RENTZMANN}

\section{Hr. minister, mine damer og herrer}

På vegne af bestyrelsen for Dansk Kriminalistforening vil jeg gerne byde velkommen til denne konference, hvormed vi festligholder foreningens 100 års jubilæum. Jeg vil gerne byde særlig velkommen til justitsminister Frank Jensen og foreningens i øjeblikket eneste æresmedlem højesteretssagfører Jon Palle Buhl og til repræsentanterne for den svenske, finske og islandske kriminalistforening. Derudover vil jeg også gerne byde særlig velkommen til tre deltagere, som er med til at tydeliggøre de historiske tråde i foreningens virke, nemlig professorinde Lise Hurwitz, som er enke efter foreningens fjerde formand professor, dr.jur. Stephan Hurwitz og professorinde Ruth Christiansen, enke efter professor, dr.jur. Karl O. Christiansen, som var initiativtager til og primus motor i Dansk Kriminologisk Selskab, der fortsat er foreningens mest aktive element samt fru Bente Lindegaard, enke efter foreningens 6 . formand, rigsadvokat Per Lindegaard. De gør foreningen en stor glæde ved på denne måde at vise interesse for foreningens fortsatte liv og virke. Og endelig et særlig velkommen til de tre indlægsholdere, Lars Nordskov Nielsen, Nils Christie og Niels Henrik Arendt.

Det er som bekendt sådan, at bestyrelsen først på et relativt sent tidspunkt, nemlig for et lille år siden blev opmærksom på, at vi muligvis var stiftet allerede i 1899 og ikke som flere troede først i 1900 hvor det første årsmøde fandt sted. Hastige historiske undersøgelser førte til, at foreningens fødsel kunne dateres til den 14. november 1899, og så fik vi travlt med at få nedsat en jubilæumskomite, som siden har arbejdet hårdt og ihærdigt på at få dagen festligholdt. Jeg vil godt benytte anledningen til at takke jubilæumskomiteen med advokat Henrik Viltoft i spidsen, og assisteret af Tine Vigild, Jens Tolstrup, Birgitte Nystrup Lundgren, Torben Rasmussen og John Madsen - alle fra kriminalforsorgen, for det meget store arbejde de har lagt i dette arrangement. Det samme har Jette Lund Karlsson fra Viltofts kontor og Sonja Elkær fra mit.

Konferencen og de øvrige aktiviteter, som finder sted i forbindelse med denne dag har naturligvis ikke kunnet etableres uden de nødvendige økonomiske midler. Disse er tilvejebragt dels igennem et generøst bidrag fra Justitsministeriet, dels af en række fonde, som er nævnt i den mappe, som konferencedeltagerne har fået udleveret. Vi har været meget taknemmelige for at disse fonde har gjort det muligt for os at fejre dagen på den måde, som vi havde planlagt.

Endelig - men ikke mindst - vil jeg takke kriminaldommer Peter Garde, som uden tøven påtog sig det utaknemmelige job i løbet af urimelig kort tid at skulle beskrive foreningens 100 årige virke. Det er et arbejde, som i betydelig grad blev vanskeliggjort af, at der ikke findes noget samlet arkiv for foreningen - det 
er vist et udslag af den udprægede normløshed, som er kendetegnende for denne forening, og som jo er en væsentlig del af det underholdende element på vore årlige generalforsamlinger. Men det er imidlertid lykkedes Peter Garde at udføre dette kæmpearbejde på den korte udmålte tid og tilmed at få løst opgaven med at beskrive foreningens glorværdige historie på en særdeles veloplagt, underholdende, oplysende og spændende måde. Dette værk har i sig selv givet foreningen et løft, og vil uden tvivl være med til at skabe en større identitetsfølelse og bevidsthed - måske endog selvbevidsthed - $\mathrm{i}$ foreningen end det har været tilfældet $i$ hvert fald de seneste mange år.

Til allersidst skal jeg takke samme Peter Garde samt Vagn Greve og Hans Henrik Brydensholt for deres kronikker, som bringes i forskellige aviser her omkring jubilæumsdagen, og som alle tager deres udgangspunkt $i$ kriminalistforeningens 100 års jubilæum og sætter det i relation til en række af de aktuelle problemer, som vi står i i dagens Danmark.

Det kan godt være, at der er mange uden for foreningens rækker, som er lidt i tvivl om, hvad en kriminalist egentlig er for en. Jeg ser, at der i en af de nævnte kronikker står, at det bl.a. er en, der beskæftiger sig praktisk med kriminalitet. Jeg ved nu ikke om det er helt dækkende. Jeg har knap 10.000 i min varetægt, som i meget høj grad beskæftiger sig praktisk med kriminalitet, uden at man vist af den grund vil kalde dem kriminalister. De er ikke udelukket fra den betegnelse, men heller ikke selvskrevne til den. Lige så lidt som betegnelsen kriminalist er synonymt med kriminel, så er det det heller ikke med kriminolog eller kriminalpolitiker. Og i modsætning til disse begreber er det heller ikke et begreb, som man finder beskrevet i nogen ordbog. I virkeligheden betyder det vel ikke andet end en person, der beskæftiger sig med hvad et samfund stiller op med kriminaliteten. Og det er ikke noget, der kræver nogen bestemt professionel baggrund. De fleste medlemmer er godt nok advokater, dommere, politifolk og anklagere, kriminalforsorgsfolk, universitetslærere og studerende. Men et nærstudium af foreningens medlemskartotek vil sikkert afsløre, at der er mange med helt andre baggrunde. Dét, der er den afgørende kvalifikation, er den samme som stod i opråbet om foreningens stiftelse den 14 . november 1899 , hvor foreningen blev oprettet for, som det hed "alle, der anser det for ønskeligt, at der i saa vide Kredse som muligt vækkes Interesse for og Forstaaelse for Strafferettens Problemer og særligt de moderne Bevægelsers Betydning for samme ....”. Og i den forstand tror jeg alle tilstedeværende vil kunne kalde sig sande kriminalister.

Vi i bestyrelsen og i arrangementskomiteen er meget glade for, at så mange har villet deltage i dagens program og ikke mindst at justitsminister Frank Jensen har gjort foreningen den glæde at ville være til stede her i dag, sådan som hans forgænger Karl Goos var det ved foreningens første møde i september 1900, og som Niels Busch Jensen var det ved foreningens 50 års jubilæum..

En særlig glæde er det, at justitsministeren også har indvilget $i$ at åbne denne jubilæumskonference, og jeg vil derfor nu give ordet til justitsministeren. 